\title{
RESILIENSI MASYARAKAT KAMPUNG CADAS GANTUNG KABUPATEN BANDUNG
}

\author{
OLEH: \\ FIRDHIA ARRAHMA ${ }^{1}$, HADIYANTO ARRACHIM ${ }^{2}$, MAULANA IRFAN ${ }^{3}$ \\ 1. Mahasiswa Program Studi Sarjana (S-1) Kesejahteraan Sosial Fakultas Ilmu Sosial dan Ilmu Politik Universitas Padjadjaran \\ 2. Pusat Studi Kewirausahaan Sosial, CSR dan Pengembangan Masyarakat Fakultas Ilmu Sosial dan Ilmu Politik Universitas \\ Padjadjaran \\ 3. Departemen Kesejahteraan Sosial Fakultas Ilmu Sosial dan Ilmu Politik Universitas Padjadjaran \\ E-mail: \\ (firdhiaa@gmail.com; hrachim@yahoo.co.id; mirfan crb@yahoo.com)
}

\begin{abstract}
ABSTRAK
Kemiskinan adalah keadaan dimana terjadi ketidakmampuan untuk memenuhi kebutuhan dasar seperti pangan, sandang dan papan. Fenomena kemiskinan ini banyak terjadi pada setiap ruang dan kalangan masyarakat, khususnya pada masyarakat di negara berkembang seperti halnya Indonesia.

Fenomena sosial mengenai kemiskinan ini terjadi pula di salah satu kampung yang berada di Bandung, Jawa Barat yaitu pada Kampung Cadas Gantung. Dimana yang diberitakan oleh media, terdapat adanya keterbatasan dalam pemenuhan kebutuhan dan ketidakcekatan pemerintah dalam meberikan layanan kebutuhan bagi mereka. Secara fisik kemiskinan ini memang terjadi pada Masyarakat Kampung Cadas Gantung. Akan tetapi, masyarakat tidak begitu membebani atas masalah yang dirasakan. Masyarakat Kampung Cadas Gantung sendiri memang sudah lama hidup berdampingan dengan lingkaran keluarganya. Melainkan, masyarakat disana pun banyak melakukan kegiatankegiatan positif dan mempercayai terhadap nilai-nilai yang mereka miliki. Sehingga, dari sinilah adanya ketertarikan peneliti untuk melakukan penelitian terhadap upaya-upaya yang dilakukan oleh Masyarakat Kampung Cadas Gantung dengan tidak merasakan adanya masalah yang mereka hadapi, khususnya masalah kemiskinan. Ternyata upaya-upaya tersebut masuk ke dalam sebuah proses penyelesaian masalah yang disebut dengan resiliensi.
\end{abstract}

Resiliensi ini merupakan kemampuan seseorang atau individu dalam bertahan diri menghadapi masalah atau kerentanan dalam hidupnya. Tujuan dari penelitian ini adalah memfasilitatori adanya upaya-upaya penyeselesaian masalah kemiskinan dengan menggunakan resiliensi yang mereka miliki.

Kata Kunci : Kemiskinan, Fenomena Kemiskinan, Resiliensi

\section{Pendahuluan}

Saat ini masalah ekonomi sudah mengarah pada masalah yang lebih spesifik yaitu mengenai masalah kemiskinan. Masalah kemiskinan ini kemudian menjadi kajian bagi beberapa sudut pandang. Kemiskinan dapat dilihat dari dua sisi yaitu kemiskinan absolut dan kemiskinan relatif. Kemiskinan absolut dan 
kemiskinan relatif adalah konsep kemiskinan yang mengacu pada kepemilikan materi dikaitkan dengan standar kelayakan hidup seseorang atau kekeluarga. Namun, agar lebih jelasnya dapat kita ketahui adanya tingkat kemiskinan di Indonesia yang tertera pada pernyataan di bawah ini :

"Pada tahun 2009 dengan tingkat kemiskinan sebesar 14,15 persen, jumlah orang yang berada di bawah garis kemiskinan adalah sebesar 32,53 juta individu. Angka ini cukup besar khususnya jika dibandingkan dengan jumlah orang miskin di negara-negara tetangga. Ini menjadi tantangan yang mendapat perhatian di awal periode pemerintahan SBY-Boediono. Selain perlambatan penurunan tingkat kemiskinan dan jumlah orang miskin, kerentanan kemiskinan juga merupakan masalah tersendiri. (http://www.tnp2k.go.id/id/kebijakanpercepatan/perkembangan-tingkatkemiskinan/ di unduh pada pukul 01.00 WIB, tanggal 12 Juni 2017)

Menurut kabar informasi yang tertera di atas, terdapat situasi kemiskinan yang terjadi pada masyarakat di Indonesia. Dimana terjadi sebuah kenaikan angka penduduk miskin yang terbilang cukup besar. Hal ini juga menjadi sebuah perhatian besar bagi beberapa pihak khususnya bagi seorang Kepala Negara atau Presiden. Kemiskinan ini dapat ditinjau dari beberapa aspek diantaranya yaitu, keterkaitan dengan jumlah penduduk miskin, tingkat kemiskinan dan kerentanan terhadap kemiskinan.

Namun, dua tahun setelah itu terjadi pula pergeseran pada jumlah penduduk miskin di Indonesia. Pergeseran penduduk miskin ini dinyatakan dalam data BPS ( Badan Pusat Statistik) pada bulan September 2012.
"Pada bulan September 2012, jumlah penduduk miskin (penduduk dengan pengeluaran per kapita per bulan di bawah Garis Kemiskinan) di Indonesia mencapai 28,59 juta orang $(11,66$ persen), berkurang sebesar 0,54 juta orang $(0,30$ persen $)$ dibandingkan dengan penduduk miskin pada Maret 2012 yang sebesar 29,13 juta orang $(11,96$ persen). Selama periode Maret 2012-September 2012, jumlah penduduk miskin di daerah perkotaan berkurang 0,14 juta orang (dari 10,65 juta orang pada Maret 2012 menjadi 10,51 juta orang pada September 2012), sementara di daerah perdesaan berkurang 0,40 juta orang (dari 18,48 juta orang pada Maret 2012 menjadi 18,08 juta orang pada September 2012). Selama periode Maret 2012 s/d September 2012, persentase penduduk miskin di daerah perkotaan dan perdesaan tercatat mengalami penurunan. Persentase penduduk miskin di daerah perkotaan pada Maret 2012 sebesar 8,78 persen, turun menjadi 8,60 persen pada September 2012. Sementara penduduk miskin di daerah perdesaan menurun dari 15,12 persen pada Maret 2012 menjadi 14,70 persen pada September 2012.". (https://www.bps.go.id/Brs/view/id/165, di unduh pada pukul 01.15 WIB, pada tanggal 12 Juni 2017)

Menurut penjelasan di atas, selama 7 bulan dalam satu tahun tersebut terdapat penurunan penduduk miskin di daerah perkotaan dan perdesaan. Hal ini ditunjukkan pula dengan adanya persentasi penurunan angka kemiskinan tersebut. Akan tetapi, pada penurunan angka kemiskinan ini lebih banyak dialami oleh daerah perdesaan. Selain itu, kemiskinan ini berkaitan juga dengan adanya sumbangan garis kemiskinan makanan. Dimana kemiskinan ini memang dapat diukur dengan adanya pemenuhan kebutuhan pokok yang dilakukan oleh individu-indvidu di masyarakat. Agar lebih jelasnya akan dijelaskan pada 
pendeskripsian terkait dengan sumber garis kemiskinan.

"Sumbangan Garis Kemiskinan Makanan terhadap Garis Kemiskinan pada September 2012 tercatat sebesar 73,50 persen, kondisi ini tidak berbeda dengan kondisi Maret 2012 yang juga sebesar 73,50 persen. Komoditi makanan yang berpengaruh besar terhadap nilai Garis Kemiskinan di perkotaan relatif sama dengan di perdesaan, diantaranya adalah beras, rokok kretek filter, gula pasir, telur ayam ras, mie instan, tempe, dan tahu. Sedangkan, untuk komoditi bukan makanan diantaranya adalah biaya perumahan, pakaian jadi anak-anak, pakaian jadi perempuan dewasa, dan bensin. Pada periode Maret 2012September 2012, Indeks Kedalaman Kemiskinan (P1) dan Indeks Keparahan Kemiskinan (P2) menunjukkan kenaikan. Ini mengindikasikan bahwa rata-rata pengeluaran penduduk miskin cenderung semakin menjauhi Garis Kemiskinan dan ketimpangan pengeluaran penduduk miskin juga semakin melebar." (https://www.bps.go.id/Brs/view/id/165, di unduh pada pukul 17.15 WIB, pada tanggal 13 Juni 2017)

Menurut penjelasan di atas, bahwasannya ada keterkaitan antara komoditi makanan dengan nilai garis kemiskinan. Yang dimaksud dengan nilai komoditi makanan itu ialah nilai jual pada makanan pokok dan dana operasional untuk memenuhi kebutuhan sehari-hari. Pada kenyataanya nilai komoditi makanan dengan garis kemiskinan anatara masyarakat perdesaan dengan masyarakat perkotaan ialah sama.

Masalah kemiskinan tidak berhenti sampai adanya kepuasan terhadap pemenuhan kebutuhan saja. Melainkan, dengan adanya masalah kemiskinan yang dirasakan oleh bersama ini dapat pula diselesaikan bersama. Dimana perlu adanya kerjasama antara masingmasing kalangan, seperti halnya, masyarakat, pemerintah dan organisasi non-pemerintah. Masalah kemiskinan memang dapat dirasakan oleh masyarakat yang tinggal di perkotaan dan di perdesaan. Namun, saat ini masalah kemiskinan identik dilatarbelakangi oleh penduduk miskin. Dimana penduduk miskin ini merupakan bagian dari masyarakat yang tidak lain bertempat tinggal di sebuah kampung atau sebuah desa. Di daerah Jawa Barat sendiri, masih banyak beberapa kota maupun kabupaten yang masih terindeks memiliki anggota masyarakat miskin.

Seperti halnya pada tabel di bawah ini telah terlampirkan kota/kabupaten di Jawa Barat yang memiliki kuantitas penduduk miskin di dalamnya :

Jumlah dan Persentase Penduduk Miskin, Indeks Kedalaman Kemiskinan (P1), Indeks Keparahan Kemiskinan (P2), dan Garis Kemiskinan Menurut Kabupaten/ Kota 


\begin{tabular}{|l|l|l|l|l|}
\hline Jurnal Penelitian \& PKM & Juli 2017 & Vol 4, No: 2 & Hal: $129-389$ & ISSN \\
\hline
\end{tabular}

Tabel 1.1. Jumlah dan Persentase Penduduk Miskin

\begin{tabular}{|c|c|c|c|c|c|c|c|c|}
\hline $\begin{array}{c}\text { Nama } \\
\text { Kabupaten/Kota }\end{array}$ & $\begin{array}{l}\text { Jml Penduduk } \\
\text { Miskin (Dlm 000) }\end{array}$ & $\begin{array}{c}\text { Persentase } \\
\text { Penduduk Miskin } \\
\text { (P0) } \\
\end{array}$ & $\begin{array}{c}\text { Indeks } \\
\text { Kedalaman } \\
\text { Kemiskinan (P1) } \\
\end{array}$ & $\begin{array}{c}\text { Indeks } \\
\text { Keparahan } \\
\text { Kemiskinan (P2) } \\
\end{array}$ & $\begin{array}{c}\text { Garis Kemiskinan } \\
\text { (Rp/Kapita/Bulan } \\
\text { ) }\end{array}$ & $\begin{array}{l}\text { Jml Penduduk } \\
\text { Miskin (P0) }\end{array}$ & $\begin{array}{c}\text { Indeks } \\
\text { Kedalaman } \\
\text { Kemiskinan (P1) } \\
\end{array}$ & $\begin{array}{l}\text { Indeks Keparan } \\
\text { kemiskinan (P2) }\end{array}$ \\
\hline Bogor & 487,10 & 8,96 & 1,58 & 0,46 & 290.874 & 490,80 & 8,83 & 1,31 \\
\hline Sukabumi & 217,86 & 8,96 & 1,22 & 0,25 & 260.068 & 198 & 8,13 & 1,21 \\
\hline Cianjur & 273,90 & 12,21 & 1,85 & 0,45 & 287,939 & 261,39 & 11,62 & 1,93 \\
\hline Bandung & 281,04 & 8,00 & 1,52 & 0,43 & 275,562 & 272,65 & 7,61 & 1,00 \\
\hline Garut & 325,67 & 12,81 & 2,07 & 0,54 & 241.068 & 298,52 & 11,64 & 1,79 \\
\hline Tasikmalaya & 208,12 & 11,99 & 1,90 & 0,45 & 255.440 & 195,61 & 11,24 & 1,78 \\
\hline Ciamis & 104,87 & 8,98 & 1,31 & 0,30 & 296.647 & 98,77 & 8,42 & 1,17 \\
\hline Kuningan & 147,21 & 13,97 & 2,32 & 0,62 & 276.154 & 144,07 & 13,59 & 2,20 \\
\hline Cirebon & 313,21 & 14,77 & 2,42 & 0,57 & 327.032 & 288,49 & 13,49 & 2,21 \\
\hline Majalengka & 167,50 & 14,19 & 2,34 & 0,60 & 379.354 & 152,50 & 12,58 & 2,06 \\
\hline Sumedang & 129,03 & 11,36 & 1,82 & 0,45 & 281.649 & 120,60 & 10,57 & 1,57 \\
\hline Indramayu & 253,12 & 14,98 & 2,37 & 0,62 & 379.088 & 237,00 & 13,95 & 1,69 \\
\hline Subang & 187,11 & 12,27 & 2,49 & 0,81 & 295.174 & 170,37 & 11,05 & 1,68 \\
\hline Purwakarta & 83,94 & 9,14 & 1,42 & 0,37 & 296.477 & 83,55 & 8,98 & 1,20 \\
\hline Karawang & 235,03 & 10,37 & 1,54 & 0,34 & 363.105 & 230,60 & 10,07 & 1,87 \\
\hline Bekasi & 169,20 & 5,27 & 0,75 & 0,16 & 394.513 & 164,41 & 4,92 & 0,83 \\
\hline Bandung Barat & 205,69 & 12,67 & 2,15 & 0,59 & 275.327 & 192,48 & 11,71 & 1,92 \\
\hline $\begin{array}{l}\text { Pangandaran } \\
\text { Kota Bogor }\end{array}$ & 41,97 & 10,76 & 1,74 & 0,43 & 303.646 & 40,14 & 10,23 & 1,53 \\
\hline Kota Sukabumi & 79,15 & 7,60 & 1,26 & 0,33 & 392.405 & 77,28 & 7,29 & 1,08 \\
\hline Kota Bandung & 27,84 & 8,79 & 1,52 & 0,41 & 421.908 & 27,51 & 8,59 & 1,36 \\
\hline Kota Cirebon & 114,12 & 4,61 & 0,72 & 0,19 & 376.311 & 107,58 & 4,32 & 0,55 \\
\hline Kota Bekasi & 31,74 & 10,36 & 1,28 & 0,26 & 358.654 & 30,15 & 9,73 & 1,86 \\
\hline Kota Depok & 146,94 & 5,46 & 0,68 & 0,15 & 497.343 & 140,03 & 5,06 & 0,69 \\
\hline Kota Cimahi & 49,97 & 2,40 & 0,23 & 0,06 & 496.747 & 50,56 & 2,34 & 0,30 \\
\hline Kota Tasikmalaya & 34,09 & 5,84 & 0,91 & 0,21 & 386.513 & 35,07 & 5,92 & 0,71 \\
\hline \multirow{2}{*}{$\begin{array}{l}\text { Kota Banjar } \\
\text { JAWA BARAT }\end{array}$} & 106,78 & 16,28 & 2,85 & 0,69 & 367.673 & 102,79 & 15,60 & 2,37 \\
\hline & $\begin{array}{l}13,42 \\
4.435,70 \\
\end{array}$ & $\begin{array}{l}7,41 \\
9,53 \\
\end{array}$ & $\begin{array}{l}0,76 \\
1,63 \\
\end{array}$ & $\begin{array}{l}0,11 \\
0,43 \\
\end{array}$ & $\begin{array}{l}271.017 \\
306,876 \\
\end{array}$ & $\begin{array}{l}12,74 \\
4.224,32 \\
\end{array}$ & $\begin{array}{l}7,01 \\
8,95 \\
\end{array}$ & $\begin{array}{l}0,73 \\
1,49 \\
\end{array}$ \\
\hline
\end{tabular}

Sumber : BPS (Badan Pusat Statistik Jawa Barat) (http://jabar.bps.go.id/LinkTabelStatis/view/id/49, di unduh pada pukul 20.00 WIB, pada tanggal 13 Juni 2017)

Jumlah penduduk miskin di Kota Bandung sendiri mencapai 114,12 juta jiwa. Sedangkan, menurut presentase penduduk miskin sendiri ternilai 4,61 \%. Kemiskinan juga dapat dilihat dari adanya indeks kedalaman kemiskinan, Kota Bandung menempati angka 0,72 \%. Mengenai keparahan kemiskinan yang dialami oleh penduduk miskin di Kota Bandung mencapai 0,19 $\%$. Sehingga, dengan adanya pengukuran secara mendalam dan penilaian dengan tinjauan parah atau tidaknya dapat melahirkan garis kemiskinan hingga mencapai kapita Rp.376.311 perbulannya.

Dengan demikian, dapat diketahui bahwasannya penduduk yang tinggal di Kota
Bandung sendiri masih banyak yang tergolong kedalam penduduk miskin. Namun, bukan berarti dengan hadirnya penduduk miskin tersebut akan selalu memberikan dampak negatif bagi kehidupan masyarakat. Melainkan perlu adanya upaya peninjauan kembali mengenai masyarakat miskin dan atau kehidupan masyarakat miskin. Dalam hal ini sesuai dengan penjelasan mengenai jenis kemiskinan yang sudah tertera pada latar belakang di halaman sebelumnya, yaitu terdapat dua jenis kemiskinan. Kemiskinan secara relatif dan kemiskinan secara absolute. Dua jenis kemiskinan ini banyak ditemui langsung di dalam kehidupan masyarakat dan dalam fenomena-fenomena kemiskinan lainnya.

Informasi mengenai fenomena kemiskinan, 
Merujuk pada berita informasi di atas, dapat diketahui adanya kuantitas kemiskinan pada masyarakat yang tinggal di Kota Bandung. Sehingga, akan menjadi mudah bagi beberapa kalangan untuk menindaklanjuti adanya isu kemiskinan. Isu kemiskinan ini juga hadir pada kehidupan masyarakat yang tinggal di Kampung Cadas Gantung, Kabupaten Bandung. Dimana terdapat sekumpulan individu yang sudah lama menetap disana. Melainkan, pada saat pelaksanaan observasi awal dengan menemui tokoh masyarakat dapat diketahui adanya kesalingtergantungan individu satu dengan individu lainnya yang diikat pula oleh hubungan darah.

Namun, memang sempat terjadi kontradiksi pendapat antara pihak beberapa informan yang sudah sempat ditemui dan diwawancarai. Menurut isi berita online mengabarkan adanya isu kemiskinan yang sangat rentan di Indonesia yaitu pada kehidupan masyarakat yang tinggal di Kampung Cadas Gantung. Dengan beberapa fenomena yang diungkap oleh narasumber di dalam berita. Fenomena-fenomena tersebut diantaranya yaitu, adanya situasi yang mengkhawatirkan bagi seorang wanita lanjut usia yang mengalami sakit dan tidak bisa berobat karena tidak adanya biaya. Selain itu, ada juga bentuk fisik yang diperlihatkan dan disebutkan oleh narasumber dalam berita online yaitu, dimana terdapat suatu keadaan yang sangat mengkhawatirkan. Dengan keadaan lingkungan yang ternilai masih rentan untuk ditempati dan lain sebagainya.

Namun, isu kemiskinan itu pun tidak lain merupakan settingan dari desakan awak media untuk memberitahukan adanya permasalahan yang serius terhadap masa. Dengan adanya fenomena kemiskinan yang terjadi pada Masyarakat Kampung Cadas Gantung membuat peneliti ingin betul mengunjungi lokasi pemukiman tersebut.

Pada observasi awal yang dilakukan peneliti telah banyak mendapatkan sumber informasi terkait dengan keselarasan pada fakta yang sebenarnya. Dimana memang terdapat masyarakat yang tinggal tidak berjauhan satu sama lainnya, masyarakat disana memang masih merupakan bagian dari masyarakat Dusun Cikored. Namun, memang dikarenakan dengan kondisi geografis yang cukup jauh itu membuat terhambatnya hubungan sosial yang baik antara masyarakat luar dengan Masyarakat Kampung Cadas Gantung. Sehingga, informasi yang sudah lama tersajikan diberita online tersebut tidak semua orang dapat mengetahui dan mempedulikannya.

Sehingga, ada pun tokoh masyarakat yang memang berkepentingan untuk melakukan suatu keperluan seperti halnya melakukan administrasi kependudukan dan menyediakan pelayanan maupun program bantuan yang berasal dari pemerintah merasa sulit akan bertemu dan mengajak diskusi Masyarakat Kampung cadas Gantung untuk melaksanakan suatu pembangunan di wilayahnya. Adapun kalimat-kalimat yang menggambarkan adanya kesulitan bagi pemerintah untuk mengajak kerjasama dikarenakan, masyarakat yang tinggal di Kampung Cadas Gantung tersebut memang malu untuk menemui apalagi berdiskusi dengan orang pendatang.

Akan tetapi, setelah peneliti mulai melakukan observasi langsung dengan menemui anggota masyarakat yang tinggal di Kampung Cadas Gantung tersebut, akhirnya peneliti dapat mengetahui adanya kontradiksi dalam penyampaian informasi dan situasi sikap yang sebenarnya dimiliki oleh mereka. Dimana terdapat penerimaan yang santun diberikan oleh masyarakat.

Sebenarnya, isu kemiskinan ini memang ada pada kehidupan mereka. Dilihat dari keadaan tempat tinggal yang terlihat sederhana dan pada saat penerimaan sebagai tamu disana. Namun, hal tersebut bukanlah sebagai penghalang bagi mereka dalam melanjutkan kehidupannya. Melainkan, mereka pun sudah nyaman dan aman dengan kehidupan yang mereka punya. Hal ini juga dipengaruhi oleh adanya keterikatan satu sama lain. Dimana mereka berkumpul karena masih dalam satu lingkaran keluarga.

Dengan adanya kekuatan atau penguat yang diberikan oleh masyarakat satu dengan masyarakat lainnya dapat pula meringankan suatu beban atau permasalahan yang ada di dalam hidupnya. Hal ini juga ternyata masuk kedalam suatu proses pada bidang keilmuan Kesejahteraan Sosial. Dimana terdapat upaya yang merupakan sumber kekuatan dalam menghadapi masalah. Upaya tersebut ialah resiliensi. Resiliensi ini merupakan kemampuan pada diri seseorang dalam bertahan diri dengan dihadapi oleh kesulitankesulitan atau masalah pada kehidupannya. 
Resiliensi ini dapat dikaitkan pula pada nilai-nilai kearifan lokal yang dimiliki oleh masyarakat dalam menghadapi masalah kemiskinan.

\section{Tinjauan Pustaka}

Dalam Soerjono Soekanto (2012) berpendapat, kemiskinan diartikan sebagai suatu keadaan dimana seseorang tidak sanggup memelihara dirinya sendiri sesuai dengan taraf kehidupan kelompok dan juga tidak mampu memanfaatkan tenaga mental, maupun fisiknya dalam kelompok tersebut. Sedangkan menurut sejarah, keadaan kaya dan miskin secara berdampingan tidak merupakan masalah sosial sampai saatnya perdagangan berkembang dengan pesat dan timbulnya nilai-nilai sosial yang baru.

Definisi lainnya, secara harfiah menurut Poerwadarminta (1976) (dalam Bambang Rustanto, kemiskinan berasal dari kata dasar miskin yang artinga "tidak berharta benda". Dengan penegrtian yang lebih luas, kemiskinan dapat dikonotasikan sebagai suatu kondisi ketidakmampuan baik secara individu, kelompok, maupun keluarga sehingga kondisi ini rentan terhadap timbulnya permasalahan sosial yang lain.

Sedangkan, menurut Kuncoro (1997) (dalam Rustanto 2012, kemiskinan didefinisikan sebagai ketidakmampuan untuk memenuhi kebutuhan standar hidup minimum. Adapun Kartasasmita (1997) dalam Bambang Rustanto, mengatakan bahwa kemiskinan merupakan masalah dalam pembangunan yang ditandai dengan pengangguran dan keterbelakangan yang kemudian meningkat menjadi ketimpangan. Hal tersebut senada dengan yang dikatakan Friedmann (1992) bahwa kemiskinan sebagai akibat dari ketidaksamaan kesempatan untuk mengakumulasi basis kekuatan sosialnya.

Akan tetapi, Brendley (dalam Ala, 1981 dalam Rustanto 2012) menyatakan bahwa kemiskinan adalah ketidaksanggupan untuk mendapatkan barang-barang dan pelayananpelayanan yang memadai untuk memenuhi kebutuhan sosial yang bahwa hal ini diperkuat oleh Salim (dalam Ala, 1981) yang menyatakan bahwa kemiskinan biasanya dilukiskan sebagai kurangnya pendapatan untuk memperoleh kebutuhan hidup yang pokok.

$$
\text { Ensiklopedia Internasional Meriam }
$$

Webster (1990) (dalam Rustanto, 2012), mendefinisikan "Poverty is scarity, dearth, or the state of one who lacks a certain amount of material possessions or money. "Kemiskinan adalah tidak memiliki apa-apa atau orang yang tidak memiliki harta benda atau uang), sedangkan, World Bank (2002) (dalam Rustanto, 2012) menyatakan "Porvety is pronounced deprivation in wellbeing". (Kemiskinan adalah istilah untuk kekurangan dalam kesejahteraan).

Narayan (2007) (dalam Rustanto, 2012) mendefinisikan kemiskinan sebagai berikut : "Poor here means lacking most or all of these assets and capabilities, material assets, bodily helath, bodily integrity, emotional integrity, information and education, organizational capacity, political representation and accountability" (Miskin disini dimaknai dengan ketiadaan aset/kekayaan dan kemampuan berorganisasi dalam ranah politik dan akuntabilitas).

Berbagai definisi yang tertera di atas, dapat disimpulkan bahwa fenomena kemiskinan yang terjadi di Indonesia sendiri dapat diartikan kedalam sebuah situasi dari ketidakmampuan seseorang baik individu maupun masyarakat untuk memenuhi kebutuhan pokoknya. Dalam hal ini dapat dilihat dari adanya fenomena-fenomena kemiskinan yang terjadi pada beberapa aspek di dalam masyarakat yaitu, pada aspek pendidikan, kesehatan, ekonomi dan lainnya.

Pada aspek pendidikan sendiri, dimana kemiskinan ini berada pada situasi seseorang dengan kemampuan melanjutkan jenjang pendidikan yang lebih rendah. Sedangkan, jika dilihat dari segi kesehatannya sendiri dimana terdapat kehidupan berkecukupan atau tidak dapat terpenuhinya sarana dan prasarana kesehatan yang layak. Aspek ekonomi sendiri memang sudah jelas-jelas dapat dengan adanya pendapatan yang dibawah standar minimum. Sehingga, dengan adanya fenomena-fenomena kemiskinan yang ada akan mempengaruhi pada faktor-faktor yang lain.

Sedangkan, dalam hal ini keterkaitan antara kerentanan dan resiliensi dengaan Kesejahteraan Sosial sendiri ialah, dimana dapat terciptanya suatu kondisi yang ada pada kehidupan masyarakat berupa kesetabilan dalam mengahadapi setiap masalah maupun ancaman 
yang ada. Melainkan, dengan adanya kerentanan dan resiliensi ini dapat pula menjadi sebuah ruang bagi seorang Pekerjaan Sosial dalam menjalankan peran-peran serta fungsinya. Dimana seorang Pekerjaan Sosial dapat memberdayakan adanya kekuatan maupun kapasitas positif yang ada pada diri masyarakat. Kekuatan dan kapasitas positif ini tidak lain seperti kearifan lokal yang dimiliki oleh masyarakat.

Selain itu, seorang Pekerjan Sosial dapat memerankan dirinya sebagai seorang fasilitator. Dimana seorang Pekerjan Sosial dapat membantu masyarakat agar lebih terbuka dengan yang lain. Sama halnya dengan masyarakat yang mengalami masalah kemiskinan, dimana perlu adanya upayaupaya bagi mereka agar bisa bersosialisasi dan berinteraksi dengan masyarakat yang lebih luas. Peran sebagai fasilitator ini merupakan ujung tombak bagi masyarakat dalam memetakan adanya permasalahan-permasalahan dan potensi yang dimiliki. Sehingga, kedepannya kerentanankerentanan di dalam masyarakat sendiri akan mudah diatasi dan terhadang oleh adanya proses resiliensi yang dilakukan oleh masyarakat dengan bantuan tenaga ahli (Pekerjaan Sosial).

Seorang Pekerjan Sosial juga dapat memerankan perannya sebagai broker. Dimana seorang Pekerjan Sosial dapat membantu membukakan pola hubungan baru atau aliansi bagi masyarakat dengan pihak pemerintah, organisasiorganisasi sosial dan lain sebagainya. Berkaitan juga dengan kehidupan masyarakat yang masuk pada katagori miskin, dimana perlu adanya pola hubungan yang baik dengan pihak luar. Hal ini ditujukkan agar masyarakat yang masuk ke dalam katagori miskin ikut serta dalam proses sosialisasi dan mereka juga dapat mudah lebih diperhatikan oleh pihak pemerintah. Sehingga, dengan adanya peran advokator ini dapat memudahkan masyarakat khususnya masyarakat miskin dalam mengakses atau memperoleh setiap pelayanan maupun proses pembangunan kesejahteraan.

Sedangkan, resiliensi sendiri adalah Resiliensi merupakan gambaran dari proses dan hasil kesuksesan beradaptasi dengan keadaan yang sulit atau pengalaman hidup yang sangat menantang, terutama keadaan dengan tingkat stres yang tinggi atau kejadian-kejadian traumatis (O'Leary, 1998; O'Leary \& Ickovics, 1995; Rutter, 1987) (dalam jurnal www.repository.usu.ac.id)
Menurut Reivich. K dan Shatte. A yang dituangkan dalam bukunya "TheResiliency Factor" menjelaskan resiliensi adalah kemampuan untuk mengatasi dan beradaptasi terhadap kejadian yang berat atau masalah yang terjadi di dalamkehidupan. Bertahan dalam keadaan tertekan, dan bahkan berhadapan dengan kesengsaraan (adversity) atau trauma yang dialami dalam kehidupannya (Reivich. K \& Shatte. A, 2002) (dalam jurnal www.repository.usu.ac.id)

Dari berbagai pengertian resiliensi dikemukakan di atas, resiliensi merupakan proses adaptasi dengan baik meskipun kerap dihadapi dengan masalah atau kerentanan. Resiliensi merupakan solusi untuk menyelesaikan permasalahan di masyarakat dan memunculkan kembali adanya kapasitas kekuatan yang dimiliki oleh masyarakat.

Kearifan lokal merupakan nama lain dari local wisdom ini dapat dipahami sebagai usaha manusia dengan menggunakan akal budinya (kognisi) untuk bertindak dan bersikap terhadap sesuatu, objek, atau peristiwa yang terjadi dalam ruang tertentu.

Secara umum kearifan lokal ini muncul melalui proses internalisasi yang panjang dan berlangsung turun-menurun sebagai akibat dari interaksi antara manusia dengan lingkungannya. Proses evolusi yang panjang ini bermuara pada munculnya sistem nilai yang terkristalisasikan dalam bentuk hukum adat, kepercayaan dan budaya setempat.

Kerangka pemikiran yang akan dipakai oleh peneliti yaitu berupa adanya keterkaitan antara isu kemiskinan yang terjadi di dalam Masyarakat Cadas Gantung dengan proses resiliensi yang sudah ada di dalam diri mereka dibantu dengan adanya nilai-nilai kearifan lokal yang dimiliki oleh masyarakat.

\section{Metodologi}

Untuk memahami sebuah fenomena sosial maupun gejala-gejala sosial lainnya, perlu adanya pemilihan dan pemakaian metode yang tepat dalam melakukan penelitian berupa penelitian deskriptif kualitatif.

Karena, hal ini sangat berpengaruh pula terhadap keberhasilan suatu penelitian. Penelitian yang akan dilaksanakan ini bertujuan untuk mengetahui gambaran terkait resiliensi atau daya 
lenting pada Masyarakat Kampung Cadas Gantung. Selain itu, penelitian ini bertujuan ntuk mengetahui resiliensi atau daya lenting pada Masyarakat Kampung Cadas Gantung dalam mengatasi masalah kemiskinan.

Selain itu, dengan adanya isu kemiskinan yang ada bahwa metode penelitian kualitatif dengan alat bantu studi kasus ini akan memudahkan bagi seorang peneliti dalam mencaritahu lebih dalam terkait dengan informasi yang dikemukakan oleh narasumber. Dimana terdapat proses tanya-jawab yang dilakukan oleh pewawancara dengan narasumber. Sesuai juga dengan proses penelitian yang akan dilakukan pada Masyarakat Kampung Cadas Gantung terkait dengan resiliensi yang mereka miliki.

Pada penelitian ini informan dipilih dengan menggunakan purposive sampling. Purposive sampling adalah teknik pengambilan sampel sumber daya dengan pertimbangan tertentu.

\section{Hasil}

Pada penelitian ini dilakukan teknik purposive sampling. Dimana terdapat proses pengambilan sampel terhadap sumber daya maupun sumber informasi sesuai dengan kebutuhan dan tujuan dari adanya proses pencapaian.

Teknik purposive sampling ini nantinya akan digunakan untuk membantu dalam proses penelitian di lapangan. Sebagaimana layaknya seorang peneliti harus bisa menemukan dan mentukan informan yang sesuai dengan kriteria. Informan tersebut berasal dari ruang lingkup masyarakat seperti halnya ketua RT,RW dan tokoh masyarakat lainnya. Dimana beberapa tokoh tersebut dapat mengetahui situasi lapangan dan memiliki pengetahuan lainnya serta mampu untuk diajak bekerjasama.

Terkait dengan hasil informasi yang telah dimiliki merupakan dari hasil wawancara pertama secara langsung dengan beberapa tokoh masyarakat, warga masyarakat yang tinggal di Dusun Cikored dan Masyarakat Kampung Cadas Gantung. Sehingga, dengan adanya proses observasi awal yang dilakukan tersebut dapat memberikan kejelasan informasi terkait fakta yang sebenarnya. Telah dilakukan proses pengklarifikasian informasi yang sempat menjadi topik hangat di dalam berita online terkait isu kemiskinan yang menimpa Masyarakat Kampung Cadas Gantung.

1. Pemilihan informan beserta informasi yang akan digali, seperti pada tabel di bawah ini :

Tabel 3.1 Informasi yang dibutuhkan

Kebutuhan informasi Informan

a. Klarifikasi informasi - Tokoh masyarakat mengenai isu - Warga masyarakat di kemiskinan di berita luar Masyarakat online. Kampung Cadas

b. Penggalian fakta- Gantung. fakta dan opini terkait - Masyarakat Kampung dengan fenomena Cadas Gantung. kemiskinan yang ada.

c. Penggalian sumber informasi awal terkait potensi dan masalah.

\section{Simpulan}

Masalah kemiskinan ini banyak memberikan dampak bagi kehidupan bersama. Dampak-dampak yang ditimbulkan diantaranya yaitu, berupa adanya ketidakberdayaan yang dirasakan oleh masyarakat dalam menghadapi situasi genting. Salah satunya yaitu, terdapat fenomena keterbatasan atas pemenuhan kebutuhan pokok di dalam keluarganya. Akan tetapi, kemiskinan juga dapat dijadikan sebagai suatu permasalahan yang terlihat biasa, jika terdapat upaya-upaya lain yang dilakukan oleh masyarakat untuk menghadapi permasalah tersebut.

Hal ini juga serupa sudah dialami oleh masyarakat yang tinggal di Kampung Cadas Gantung. Dimana mereka merupakan sekumpulan individu-individu yang tinggal bersampingan dan dilatarbelakangi oleh kesamaan budaya dan keyakinan serta hubungan darah.

Masalah kemiskinan ini terjadi pada Masyarakat Kampung Cadas Gantung. Dimana secara fisik terlihat adanya kehidupan yang sederhana. Dengan kondisi wilayah yang kurang strategis tersebut dapat mempengaruhi adanya keterbatasan mereka dalam memperoleh kebutuhan selama hidupnya. Namun tidak demikian, masyarakat yang tinggai Kampung Cadas Gantung sendiri hingga saat ini masih saja hidup dalam suatu kebersamaan dan kecukupan. Dimana mereka pun sudah merasakan adanya kehidupan yang tidak lain ternilai "sulit". Akan 


\begin{tabular}{|c|c|c|c|c|}
\hline Jurnal Penelitian \& PKM & Juli 2017 & Vol 4, No: 2 & Hal: $129-389$ & $\begin{array}{c}\text { ISSN } \\
2442-448 X(\mathrm{p}), 2581-1126(\mathrm{e})\end{array}$ \\
\hline
\end{tabular}

tetapi, dengan adanya keadaan yang demikian tidak membuat mereka untuk berhenti dengan adanya kepesimisan dalam hidup. Sehingga, hal tersebut tergolong kedalam upaya resiliansi dalam menghadapi masalah yang ada.

\section{Daftar Pustaka}

Raharjo, ST. 2015. Assessment untuk Praktik Pekerjaan Sosial dan Kesejahteraan Sosial. Bandung: Unpad Press 2015. Dasar Pengetahuan Pekerjaan Sosial. Bandung: Unpad Press. 2015. Keterampilan Pekerjaan Sosial: Dasar-dasar. Bandung, Unpad Press.

Rustanto, Bambang. 2015. PENELITIAN KUALITATIF PEKERJAAN SOSIAL. Bandung: REMAJA ROSDAKARYA.

Rustanto, Bambang. 2015. Menangani Kemiskinan. Bandung: REMAJA ROSDAKARYA.

Wibhawa, Budhi, dkk. 2014. DASAR-DASAR Pekerjaan Sosial. Bandung: widya PADJADJARAN.

Wikantiyoso, Respati dkk. 2009. KEARIFAN LOKAL DALAM PERENCANAAN DAN PERANCANGAN KOTA Untuk Mewujudkan Arsitektur Kota yang Berkelanjutan. Malang: Group Konservasi Arsitektur \& Kota.

Soekanto, Soejono. 2012. SOSIOLOGI SUATU PENGANTAR. Jakarta: RAJAGRAFINDO PERSADA.

Sugiyono. 2012. METODE PENELITIAN KUANTITATIF KUALITATIF DAN $R \& D$. Bandung: ALFABETA. 